\title{
Development of Flipped Classroom Strategy in Teaching Reading
}

\author{
Erwin Hari Kurniawan, M.Pd \\ FKIP UNISKA KEDIRI, INDONESIA \\ erwinharikurniawan@gmail.com \\ Sri Wulandari, M.Pd \\ FKIP UNISKA KEDIRI, INDONESIA \\ Sw66941@gmail.com \\ M. Syaichul Muchyidin, M.Pd \\ FKIP UNISKA KEDIRI, INDONESIA \\ kidin_oke@yahoo.com
}

\begin{abstract}
Flipped Classroom is a teaching strategy that combines technology in traditional teaching which today is commonly called blended learning. The flipped classroom is an opposite of traditional instructional procedures, usually done in the classroom in traditional learning to be performed at home in the flipped classroom, and usually carried out at home as homework in traditional learning to be implemented in the classroom in the flipped classroom. This research develops the teaching strategy involving Padlet as open source in making webinar for being accessed easily by students by connecting teaching video created from power point using Bandicam and uploaded on YouTube, as media in teaching learning process, and Quiz Creator as the evaluation accessed by students. The result of this study is the students become more active and aware to use technology as the aid of teaching learning process.
\end{abstract}

\section{Keywords—flipped classroom; reading; blended learning}

\section{INTRODUCTION}

According to reference [1] reading is useful for language acquisition. Provided that students more or less understand what they read, the more they read, the better they get at it. Reference [2] states that reading is a complex "cognitive process" of decoding symbols in order to construct or derive meaning as in reading comprehension. Reading is a meaning of language acquisition, communication, and of sharing information and ideas. Like all languages, it is a complex interaction between the text and the reader which is shaped by the reader's prior knowledge, experiences, attitude, and language community which is culturally and socially situated. The reading process requires continuous practice, development, and refinement. Because reading is such a complex process, it cannot be controlled or restricted to one or two interpretations. There are no concrete laws in reading, but rather allows readers an escape to produce their own products introspectively. This promotes deep exploration of texts during interpretation.

The purpose for reading also determines the right approach to understanding the reading. Someone who needs to know if he can afford to eat at a restaurant definitely needs the pricing information provided on the menu, and no need to rename any.

Reference [3] based on L2's underlying theory of reading and understanding text with multimedia, discusses "how L2 reads more advanced research on cognitive processes involved in reading, that is, downstream diodes, Up like a process of vocabulary with a higher level, top-down process like activating prior knowledge ". They join this with existing research on learning with technology to find out how students with different learning abilities are put together "verbal and visual information".

Learning strategy is one of the training programs that includes the form and ability in a learning. According to reference [4] the world of education, strategy is defined as planning that contains about a series of activities designed to achieve certain educational goals. The learning strategy is a learning activity that must be done teachers and students for the purpose to be effective, efficiently and efficiently.

Reference [5] states that Flipped classroom is an instructional strategy and a type of blended learning that reverses the traditional educational arrangement by delivering instructional content, often online, outside of the classroom. It moves activities, including those that may have traditionally been considered homework, into the classroom. In a flipped classroom, students watch online lectures, collaborate in online discussions, or carry out research at home and engage in concepts in the classroom with the guidance of the instructor. Based on reference [6] a teacher's interaction with students in a flipped classroom can be more personalized and less didactic, and students are actively involved in knowledge acquisition and construction as they participate in and evaluate their learning.

In traditional learning, students are taught subject matter by teachers in the classroom (through lectures or direct explanations from teachers, group discussions, or reading and observing), then doing homework assignments (PR). In the contrary, in the flipped classroom, students study the subject matter at home (through watching video lessons, making 
summaries, noting key points, making inquiries, discussing with friends online, or reading needed sources), then working on tasks for reinforcement in the classroom. In the classroom there is also discussion, practice, explanation of concepts that students have not understood, but this is for strengthening. Based on the above exposure, the development of flipped classroom can be used as a strategy in the pursuit of reading in UNISKA Kediri.

\section{LITERATURE REVIEW}

The principles of teaching reading: First, exploit the reader's background knowledge. Second, build a strong vocabulary base. Third, teach for comprehension. Fourth, work on increasing reading rate. Fifth, teach reading strategies. Sixth, encourage readers to transform strategies into skills. Seventh, build assessment and evaluation into your teaching. Eighth, strive for continuous improvement as a reading teacher.

Blended learning based on reference [7] is a studentcentered approach to creating a learning experience whereby the learner interacts with other students, with the instructor, and with content through thoughtful integration of online and face-to-face environments.

The term flipped classroom was popularized by teachers Aaron Sams and Jon Bergman from Woodland Park High School, Colorado in 2007 in response to a realisation that class time would be best spent guiding knowledge and providing feedback rather than delivering direct instruction. According to reference [8], there are some pillars of Flipped Classroom, those are: 1) Flexible Environment. Flipped Learning allows for a variety of learning modes. 2) Learning Culture. The Flipped Learning model deliberately shifts instruction to a learner-centered approach, where in-class time is dedicated to exploring topics in greater depth and creating rich learning opportunities. 3) Intentional Content. Flipped Learning Educators continually think about how they can use the Flipped Learning model to help students develop conceptual understanding, as well as procedural fluency. 4) Professional Educator. The role of a Professional Educator is even more important, and often more demanding, in a Flipped Classroom than in a traditional one as in Fig. 1.

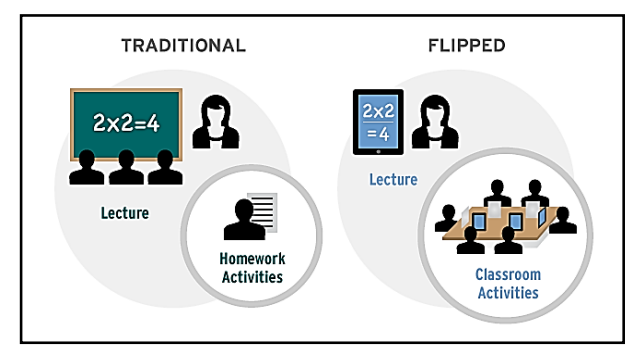

Fig. 1. Traditional classroom versus flipped classroom.

\section{METHOD}

The design of this research is a procedural model. It means that the development follows some stages that must be taken to produce the product. Since this study intended to develop supplementary English material, the Research and Development (R\&D) design employed. The model of development carried out in this study is similar to reference [9] System Approach Model. It is chosen as the design model for this project for several reasons. First, it is widely known as a model that can applied to a variety of context areas by novice to expert instructional designers. Second, this model based on a systematic process.

This research only focused on developing teaching strategy in teaching critical reading in FKIP Uniska Kediri. The procedure of materials development can be seen in Fig. 2.

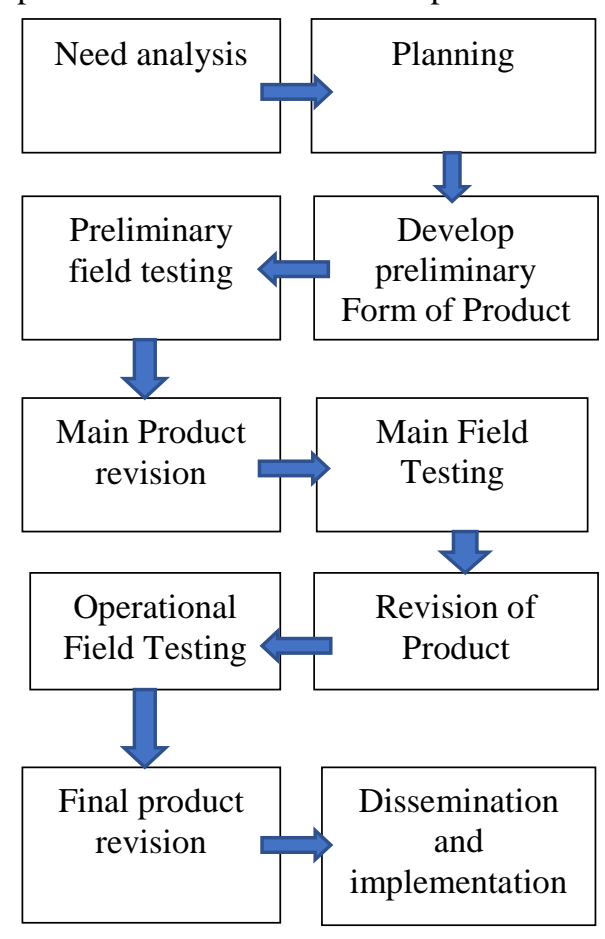

Fig. 2. The model of development adapted from Borg and Gall (2006)

Firstly, need survey and its result was used to develop the teaching strategy. Then, when the draft was ready, it was tested and revised. After main product revision, there was main field testing to wider scope. Then, the product was revised and tested on the wider field. Finally, the product became the final product.

\section{RESULT}

From the survey and interview, it was found that the teaching learning process in reading had not used blended learning in the process.

After knowing the condition, the researchers did collecting data related to the process of teaching using flipped classroom and some softwares and Learning Management System used to support this strategy. In the (LMS) application, teaching reading using Padlet as LMS to present the video uploaded in Youtube, and other teaching materials. 
At first, the researchers planned to arranged the topic used in teaching critical reading. After that the researcher made material compiled from several books and internet. Then the researchers tried to compile the material used Lectora inspire as media used to be uploaded in Padlet. After knowing the difficulty in constructing material using it, the researcher considered to use power point as supporting material to be presented and uploaded in in Padlet.

The topic which is used in this research is as in the following table.

TABLE I. TOPIC USED IN APPLYING RESEARCH AND DEVELOPMENT IN TEACHING CRITICAL READING

\begin{tabular}{|c|c|c|}
\hline No & Meeting & Topic \\
\hline 1 & First Meeting & $\begin{array}{l}\text { Learning Contract and } \\
\text { introducing flipped Classroom } \\
\text { strategy }\end{array}$ \\
\hline 2 & Second Meeting & $\begin{array}{l}\text { Chapter 1: Understanding } \\
\text { Structure: Active Reading }\end{array}$ \\
\hline 3 & Third Meeting & $\begin{array}{l}\text { Chapter 2: Understanding } \\
\text { Structure: Patterns of } \\
\text { Organization and Supporting } \\
\text { Details }\end{array}$ \\
\hline 4 & Fourth Meeting & $\begin{array}{l}\text { Chapter 3: Understanding } \\
\text { Explicit Main Ideas }\end{array}$ \\
\hline 5 & Fifth meeting & $\begin{array}{l}\text { Chapter 4: Understanding } \\
\text { Implied Main Ideas }\end{array}$ \\
\hline 6 & Sixth Meeting & $\begin{array}{l}\text { Chapter 5: Understanding } \\
\text { Text Marking and Annotation }\end{array}$ \\
\hline 7 & Seventh Meeting & $\begin{array}{l}\text { Chapter 6: Understanding } \\
\text { Text Note Taking }\end{array}$ \\
\hline 8 & Eighth Meeting & $\begin{array}{l}\text { Chapter 7: Understanding } \\
\text { Arguments }\end{array}$ \\
\hline 9 & Ninth Meeting & Mid Semester \\
\hline 10 & Tenth Meeting & $\begin{array}{c}\text { Chapter 8: Evaluating } \\
\text { Arguments }\end{array}$ \\
\hline 11 & Eleventh Meeting & $\begin{array}{l}\text { Chapter 9: Evaluating Ideas: } \\
\text { Fact \& Opinion }\end{array}$ \\
\hline 12 & Twelfth Meeting & $\begin{array}{l}\text { Chapter 10: Evaluating Ideas: } \\
\text { Evidence }\end{array}$ \\
\hline 13 & Thirteenth Meeting & $\begin{array}{l}\text { Chapter 11: Evaluating Ideas: } \\
\text { The Writer's Technique }\end{array}$ \\
\hline 14 & Fourteenth Meeting & Final Examination \\
\hline
\end{tabular}

The teaching strategy that would be applied before the class consisted of several steps and tried only three times. In the first meeting, the lecturer made teaching material using power point and material to be discussed. Then, the lecturer gave module to be hand out for them. The students should have downloaded and studied it before the class. In the class they should have discussed the material and there was a test to be discussed and the groups and presented. From this, there were some suggestions, it was needed Video to make the media more interesting. the second is the time management and material presented had to be evaluated. Then in the main field testing, the procedure was tested in B1 class. The researcher made video from power point presented and uploaded into YouTube and linked into Padled. Then, before the class, the students watched the movie uploaded. After that, the students made a note based on the video uploaded and prepared questions to be discussed. Then during the class, the lecturers gave opportunity for students to ask some problem faced. Then, the lecturer gave text to be discussed in a group, it is consist of 4-5 students. After that, the lecturer asked to every group to present their discussion. In the end of the class, the lecturer gave reinforcement.

This procedures and material were testing for B1 class to get suggestion and correction from other researchers based on the field note and interview from other researchers. From these activities, there were some corrections and recommendations related to the material presented. From the first, the video needed to be added with sound recording, not only just visual. Then, the material needed some revisions to be simplifier and easy to be studied. From these activities, there were some activities done to improve the material and video presented. At the first was fixing teaching material in power point. After that the power point was presented and recorded using Bandicam before uploaded into YouTube and linked into Padlet. Besides that, it needs to make pre-test using quiz creator to know students understanding after watching video.

After revising and recording the video using Bandicam, the strategy was tested in the real object, that was in A class which consisted of 34 students. The students had to download quiz creator uploaded in Padlet and did in the class before question and asking session. The teaching strategy applied consisted before the class and during the class. In the first meeting, the lecturer gave students module to be studied. Before the class the lecturer made revision on teaching material using power point and material to be discussed. Besides that, the lecturer made pre-test before discussion session to know students' schemata and their understanding using multiple-choice test applied in quiz creator. Then, the lecturer made presentation video from power point and recorded it using Bandicam. Then, the video was uploaded into YouTube and linked into Padlet. Before the class, the students watched the movie uploaded in Padlet. After that, the students made a note based on the video uploaded and prepared questions to be discussed. The students had to download the quiz creator to be done in the class. Then, during the class, the lecturers gave opportunity for students to do the quiz in $10-15$ minutes as brain storming. Then, the students could ask some problem faced. The following, the lecturer gave text to be discussed in group consist of 4-5 students. After that, the lecturer asked every group to present their discussion. In the end of class, the lecturer gave reinforcement.

From the main field testing, there were some suggestions to revise the video and the material in discussion. There were some mispronunciations in the video and the topics in discussion which need some revisions. The teaching strategy applied based on teaching field note and interview were implemented well as the procedure in Flipped classroom. The using of video recorded made students easy to study and they could prepare the material discussion. The teaching material and video revised could be seen as in https://padlet.com/erwinhari/criticalreading2017.

From those, the strategy and teaching material would be made into a teaching reading book using flipped Classroom. And when it was ready it would be disseminated to the other 
lecturers in UNISKA to be one of teaching strategy in adapting blended learning.

\section{CONCLUSION}

From this Research, there were some conclusions, those are:

1) The teaching strategies are: making an interesting video and uploaded into YouTube and linked in to Padlet. After that the teacher uploads supporting material used in the class. The students before the class should watch video linked in Padlet, make a note and questions relates to the material that they do not understand. They also download the pre-test file to be done in the class. Then during the class: the lecturer asks students to do the pre-test. After that, the students are given time to ask and answer the question that they get from the video presented. Then, the students should discuss the text given and present it to get suggestion and correction from others. The last, the teacher gave reinforcement.

2) The function of quiz creator in pre-teaching in the class is to make students interest to learn the video presented on line, because it can stimulate their schemata toward the material to be discussed.

3) The using of Padlet makes students easy to manage the material presented without open YouTube or other links. It can focus the learning process in applying blended learning.

4) There is no homework given during applying the flipped classroom. The duty of the students are: watching and studying from the video and compare it with the hand out given.

\section{RECOMMENDATION}

The recommendation from this research are:

1) To make the presentation video must be simple and interesting to be watched. The explanation and visual presented must be attractive and simple to make them easier to understand and interesting to watch.

2) The using of pre-test in the class is useful to stimulate students to watch the presentation video. It was given before question and answer to stimulate their schemata

3) Other researchers can conduct further study to develop strategy for other subjects or level of study.

4) Other researchers can develop more varied strategy and teaching material based on the condition of the subject of research.

\section{REFERENCES}

[1] J. Harmer, How to Teach English. Hongkong: Pearson Education Limited, 2007.
[2] M. De Certeau, Reading as Poaching. The Practice of Everyday Life. Trans. Steven F. Rendall. Berkeley: University of California Press, 1984

[3] D. M. Chun, D. M., and J.L. Plass. Research on text comprehension in multimedia environments. Language Learning \& Technology, 1990.

[4] W. Sanjaya, Strategi Pembelajaran. Jakarta: Kencana Prenada Media Group, 2006.

[5] Abeysekera, Lakmal, and P. Dawson, "Motivation and cognitive load in the flipped classroom: definition, rationale and a call for research." Higher Education Research \& Development, vol. 1, pp. 1-14, 2015.

[6] B. Alvarez, "Flipping the classroom: Homework in class, lessons at home". Education Digest: Essential Readings Condensed For Quick Review, vol. 8, pp. 18-21, 2011.

[7] R. Garrison, and H. Kanuka, Blended Learning: Uncovering it Transformative Potential in Higher Education," Internet and Higher Education 7, pp. 95-105, 2004.

[8] K. M. Arfstrom, Flipped Learning Hand Out. retrieved from http://flippedlearning.org/wpcontent/uploads/2016/07/FLIP_handout_FNL_Web.pdf, 2016.

[9] Borg, R. Walter, and M.D. Gall, Educational Statistic. Longman: Michigan University, 1983. 